"Heritage tourism in India: a stakeholder's perspective"

\begin{tabular}{|c|c|c|}
\hline AUTHORS & \multicolumn{2}{|l|}{$\begin{array}{l}\text { Arun Sharma } \\
\text { Suman Sharma }\end{array}$} \\
\hline ARTICLE INFO & \multicolumn{2}{|c|}{$\begin{array}{l}\text { Arun Sharma and Suman Sharma (2017). Heritage tourism in India: a } \\
\text { stakeholder's perspective. Tourism and Travelling, 1(1), 20-33. } \\
\text { doi:10.21511/tt.1(1).2017.03 }\end{array}$} \\
\hline DOI & \multicolumn{2}{|c|}{ http://dx.doi.org/10.21511/tt.1(1).2017.03 } \\
\hline RELEASED ON & \multicolumn{2}{|l|}{ Tuesday, 26 December 2017} \\
\hline RECEIVED ON & \multicolumn{2}{|l|}{ Wednesday, 05 July 2017} \\
\hline ACCEPTED ON & \multicolumn{2}{|l|}{ Tuesday, 01 August 2017} \\
\hline & \multicolumn{2}{|c|}{$((c))$ EY-NC } \\
\hline LICENSE & \multicolumn{2}{|c|}{$\begin{array}{l}\text { This work is licensed under a Creative Commons Attribution-NonCommercial } 4.0 \\
\text { International License }\end{array}$} \\
\hline JOURNAL & \multicolumn{2}{|l|}{ "Tourism and Travelling" } \\
\hline ISSN PRINT & \multicolumn{2}{|l|}{$2544-2295$} \\
\hline PUBLISHER & \multicolumn{2}{|c|}{ LLC "Consulting Publishing Company "Business Perspectives" } \\
\hline FOUNDER & \multicolumn{2}{|c|}{ Sp. z o.o. Kozmenko Science Publishing } \\
\hline & & $\begin{array}{l}\text { ニ-: } \\
\text { =-:- }\end{array}$ \\
\hline NUMBER OF REFERENCES & NUMBER OF FIGURES & NUMBER OF TABLES \\
\hline 41 & 2 & 7 \\
\hline
\end{tabular}

(C) The author(s) 2022. This publication is an open access article. 


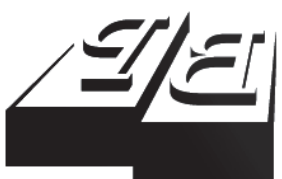

BUSINESS PERSPECTIVES

0

LLC "CPC "Business Perspectives" Hryhorii Skovoroda lane, 10, Sumy, 40022, Ukraine

www.businessperspectives.org

Received on: $5^{\text {th }}$ of July, 2017 Accepted on: $1^{\text {st }}$ of August, 2017

(c) Arun Sharma, Suman Sharma, 2017

Arun Sharma, Ph.D., Assistant Professor, Tourism Management, Maharaja Agrasen University Baddi, India.

Suman Sharma, Ph.D., Assistant Professor, Tourism Management, Central University of Himachal Pradesh, India.

\section{HERITAGE TOURISM IN INDIA: A STAKEHOLDER'S PERSPECTIVE}

\begin{abstract}
Incredible tangible and intangible heritage of India play a vital role towards the nation's overall growth and development. Ancient literature posse's sufficient references about the travelers, scholars and philosophers those preserved and portrayed the heritage for future generation which is apparently visible from various travelers' diaries, traditions and exhibitions. Despite a difficulty in finding out the right sentiment for expressing the true meaning of heritage, the concept of heritage has been explored to its core for an acceptable definition in this research study. This study suggests that heritage can act as an important holistic development tool for the overall community development. The opinion of stakeholders was recorded with the help of a questionnaire administered on local community nearby places of historic significance. The study provides ample scope and opportunities towards heritage tourism development in India as per stakes of local community. According to Mahatma Gandhi "A nation's culture resides in the hearts and in the soul of its people". Therefore local community has been considered as the ultimate ambassador for heritage and cultural tourism in this research paper.
\end{abstract}

\section{Keywords heritage, preservation, community, stakeholder}

\section{JEL Classification Z30, Z32, Z38, Z39}

\section{INTRODUCTION}

Over the past few decades, as the 'tourism studies' has emerged as an academic discipline, it has been dominated by other disciplines including economics, business and management studies. It has had very little time for the humanities, although it has accommodated important perspectives from geography, sociology and anthropology (Walton \& Cooper, 2011). On the other hand, historians have recognized the potential significance of tourism's past for their discipline at a slow pace. They are not successful to identify the global (and globalizing) importance of tourism as a transforming set of economic activities as it has emerged as the largest and most persistent global industry of the new millennium. Literature recognized that both history and heritage are interlinked as "Heritage is the modern-day use of elements of the past and is not simply the past" (Timothy \& Boyd, 2003). "Heritage is what contemporary society chooses to inherit and to pass on and history is what a historian regards as worth recording" (Turnbridge \& Asworth, 1996). According to the Oxford English Dictionary heritage is something that can be passed from one generation to the next, something that can be conserved or inherited, and something that has historic or cultural value. Heritage might be understood to be a physical 'object': a piece of property, a building or a place that is able to be 'owned' and 'passed on' to someone else (Campanella, 2013). 
In addition to these physical objects and places of heritage there are also various practices of heritage that are conserved or handed down from one generation to the next. These invisible or 'intangible' practices of heritage, such as language, culture, popular song, literature or dress, are as important in helping us to understand who we are as the physical objects and buildings that we are more used to thinking of as 'heritage'.

A country as diverse as India is symbolized by the plurality of its culture and heritage. The ancient past of India has ensured that the present and subsequent generations have abundant of historical and cultural inheritances to be proud of. The charming monuments and heritage sites in the country stand apart mutely today to paraphrase their story of delight, grief, bravery and sacrifice before visitors. The Indian Government has recognized tourism as major engine of economic growth which is visible from the heritage preservation efforts in the country. The restoration efforts to safeguard valuable heritage assets at government's end in association with various agencies and organizations are visible at few places of historic significance. But there are so many places those still stands apart and require immediate attention. This study has been conducted in a north Indian hill state 'Himachal Pradesh' settled in the lap of Western Himalaya, popularly as "Dev Bhoomi" or Land of Gods. It has abundant natural and cultural resources those make it ideal for tourism. Himachal Pradesh Economic Survey 2014-15, recognized tourism as one of the most important sectors of the economy and a major engine of growth. The contribution of the tourism sector to the state GDP is 7.5 percent which is quite significant. Being the earlier inhabited state (Balokhra, 2009) by human being (about 2 million years ago man lived in the foothills of Himachal Pradesh, in the Bangana valley of Kangra, Sirsa valley of Nalagarh and Markanda valley of Sirmour) it has huge potential and opportunity to be promoted as destination for heritage lovers (Sankhyan, 2013). With its diversification among 12 districts, 75 tehsils, 52 subdivisions, 75 blocks, 57 towns and almost more than 20000 villages (census, 2011) government has identified four major tourist circuits for the tourism. However the different theme based tourist circuits are also possible. State is adorned with 33 wildlife sanctuaries, 2 national parks, 11 museums, 1 Fossil Park, 1 war memorial, 40 ASI protected monuments and 2 UNESCO world heritage sites. This land is also a centre for creativity which is reflected from Pahari paintings, Cloth art, Metal work, Wood work, Stone work etc. Furthermore hills architectural style in itself is amazing. The prominent valleys, important mountain passes, charming lakes, hot springs, waterfalls and strategic river system along with moderate temperature boosts the natural heritage assets of the state. Along with such wonderful tourism resource base and earlier promoted tourism hub by government even before independence, surprisingly state is not able to occupy a space among top five tourist receiving states in the country.

The reason for this may be the lack of the proper exploitation of tourism resources. The valuable heritage resources are dying unnatural death, few forts are in ruin and few are in pathetic state, fossils are lying around the valleys, tourist places are facing seasonality, religious places are full of congestion and crowd, even though traditional events are victims of poor management. Therefore, there exists a necessity to preserve the heritage resources, reflect cultural identity and safeguard the natural asset in order to establish a mechanism to portray the past for the future generations.

On the basis of above argument this research is a sincere attempt to develop a heritage based tourism product in the state of Himachal Pradesh which focuses on the attraction attributes of heritage resources, and records the stakeholders (Figure 1) opinions towards such type of tourism development.

\section{LITERATURE REVIEW}

Heritage tourism is a new combination of words to look at tourism planning more comprehensively. It affirms that local community has identi- fied significant elements of their places as important enough to preserve and to pass on to future generations. Heritage tourism also denotes that people are dedicated to caring for these identified elements or resources and sharing them. In 


\begin{tabular}{|c|c|}
\hline Tourism Related & Non Tourism Related \\
\hline $\begin{array}{l}\text { Tour operators } \\
\text { Hoteliers } \\
\text { Travel agents } \\
\text { Rent a car/Bike rentals Restaurant/ } \\
\text { Bar/Coffee shops } \\
\text { Souvenir shops } \\
\text { Attraction providers }\end{array}$ & $\begin{array}{l}\text { Transport providers } \\
\text { Service providers } \\
\text { Retailers/wholesalers } \\
\text { Building/Construction } \\
\text { Farming/Fishing } \\
\text { Small industry/Manufacture } \\
\text { Electricity/ Water providers }\end{array}$ \\
\hline \multicolumn{2}{|c|}{ Stakeholders Map for Himachal Pradesh Holistic Tourism Development } \\
\hline $\begin{array}{l}\text { Public Sector Officials/Managers } \\
\text { Indian Government } \\
\text { Ministry of tourism } \\
\text { HPTDC } \\
\text { Districts of HP } \\
\text { Chambers of commerce } \\
\text { Developing organization councils } \\
\text { Local governments }\end{array}$ & $\begin{array}{l}\text { Private Sector Entrepreneurs/Managers } \\
\text { Residents } \\
\text { Ethnic community } \\
\text { NGO- nongovernmental organizations } \\
\text { Institutions } \\
\text { Trade associations } \\
\text { Government sector employees } \\
\text { Visitors }\end{array}$ \\
\hline
\end{tabular}

Figure 1. Stakeholder map for studying heritage tourism in Himachal Pradesh

sum, heritage tourism is a broad concept that covers a diverse collection of phenomena (Tweed \& Sutherland, 2007 as cited in Trinh 2013). Heritage tourism is an operational, engaging, and on-going process that involves inhabitants, social groups, civic institutions and governments working together. Various researchers have conceptualized the cultural heritage tourism as shown in Table 1.

For the purpose of this research, heritage tourism is understood as: 'the experience sought and consumed by tourists at sites of heritage importance, specifically at historic places, landscapes and culture those have not only historic value at a national level but which also possess personal, emotional, symbolic and aesthetic value'.

Tourism industry itself is a vast and interwoven network of tourism businesses, industry organizations and government agencies - all working to grow and sustain a dynamic industry by fostering fresh, innovative ideas and encouraging investment to make regions even better equipped to attract more visitors, stimulate economic activity and continue building. It is one of the most notable service industries in the world (Schumacher, 2007). According to Freeman (1984), a stakeholder is 'any group or individual who can affect or is affected by the achievement of the organization's objectives'. Thus, a group qualifies as a stakeholder if it has a legitimate interest in aspects of the organizations activities (Donaldson \& Preston, 1995) and, thus, according to Freeman, has either the power to affect the firm's performance and/ or has a stake in the firm's performance. From stakeholder's perspective, Shah and Gupta (2000) analyzed the tourism experience in Asia. Morgan et al. (2003) explored the context and creation of the New Zealand brand. This study identifies the stakeholders crucial to the delivery of this destination brand and examines the positioning process and the creation of its largely web-driven strategy. Timur and Getz (2008) examined network of inter-relationships of stakeholders representing government, the community and the tourism and hospitality industry, and their perceptions of critical stakeholders in destination development. The study demonstrates the use of a network analysis methodology as a potential tool for researchers and managers in examining destination stakeholder relationships. Local government and DMOs are perceived to hold the greatest legitimacy and power over others in destination development. Similarly Baker and Cameron (2008) identified Critical success factors in destination marketing. Batta (2003) endeavors to identify the values that stakeholders attach to the environmental resources in the Himachal Pradesh. It is argued that the recovery of these use and non-use values could play an important role in contributing funds towards the preservation and/or conservation of common-pool resources. In Indian Context (Vasudevan, 2008) studied the role of internal stakeholders in destination branding in Kerala. The 'Case Note' prepared in the context of Kerala Tourism offers an insight into the dif- 
Table 1. Definitions of cultural heritage tourism

\begin{tabular}{|c|c|c|}
\hline No & Source & Conceptualization \\
\hline 1. & Hollinshead, 1988 & $\begin{array}{l}\text { Local traditions and community cultural heritage can serve as attractions and that } \\
\text { cultural heritage tourism embraces folkloric traditions, arts, and crafts, ethnic history, } \\
\text { social customs and cultural celebrations }\end{array}$ \\
\hline 2. & Yale, 1991, p. 21 & $\begin{array}{l}\text { Tourism centered on what we have inherited, which can mean anything from historic } \\
\text { buildings to art works, to beautiful scenery }\end{array}$ \\
\hline 3. & Zeppel \& Hall, 1992, p. 47 & $\begin{array}{l}\text { A broad field of speciality travel based on nostalgia for the past and the desire to } \\
\text { experience diverse cultural landscapes and forms }\end{array}$ \\
\hline 4. & Silberberg, 1995, p. 361 & $\begin{array}{l}\text { Visits by persons from outside the host community motivated wholly or in part by } \\
\text { interest in historical, artistic, scientific, lifestyle/cultural heritage offerings of a host } \\
\text { community, region, group or institution }\end{array}$ \\
\hline 5. & Fyall \& Garrod, 1998 & An economic activity that makes use of socio-cultural assets to attract visitors \\
\hline 6. & Richards, 2000, p. 9 & $\begin{array}{l}\text { Cultural heritage tourism is largely concerned with the cultural legacy of the past, or } \\
\text { the 'hard' cultural resources usually contained in buildings, museums, monuments and } \\
\text { landscapes or represented and interpreted in a specialized "cultural heritage centers" }\end{array}$ \\
\hline 7. & Ashworth, 2000, p. 190 & $\begin{array}{l}\text { The commodified artifacts, buildings, memories and experiences of the past that entails } \\
\text { cooperation of between cultural heritage producers, the tourism industry and local place } \\
\text { managers }\end{array}$ \\
\hline 8. & Prentice 2001, p. 8 & $\begin{array}{l}\text { Tourism constructed, proffered and consumed explicitly or implicitly as cultural } \\
\text { appreciation, either as experiences or schematic knowledge gaining }\end{array}$ \\
\hline 9. & Munt \& Mowforth, 2003 & $\begin{array}{l}\text { Cultural heritage tourism is a 'new tourism' in a post-Fordist economy, associated with } \\
\text { the emergence of a new middle class }\end{array}$ \\
\hline 10. & McCain \& Ray, 2003, p. 713 & $\begin{array}{l}\text { It includes tourism related to what we have inherited. This may mean interest in our } \\
\text { connections to anything from history, art, science, lifestyles, architecture, to scenery } \\
\text { found in a community, region, population, or institution that we regard as part of our } \\
\text { collective lineage }\end{array}$ \\
\hline 11. & Poria et al., 2003, p. 248 & $\begin{array}{l}\text { A subgroup of tourism, in which the main motivation for visiting a site in based on the } \\
\text { place's cultural heritage characteristics according to the tourists' perception of their own } \\
\text { heritage }\end{array}$ \\
\hline 12. & Jamal \& Kim, 2005, p. 78 & $\begin{array}{l}\text { Cultural heritage tourism brings pasts, peoples, places and cultures into performative } \\
\text { contestation and dialogue. It is a social-cultural phenomenon important to personal, } \\
\text { local and global social life }\end{array}$ \\
\hline
\end{tabular}

ferent internal audiences in case of a place brand, and what branding initiatives mean to them. The paper also tries to understand the obvious and latent connotations of an internal branding exercise. In the context of Himachal tourism Singh (2008) studied the destination development dilemma in Manali. The article commences with the argument that the discernment of the purpose and limits of destination development are crucial for its sustainability. Consequently, it is recommended that interest groups focus their attention on the long-term viability of the core product, primarily, to avoid unacceptable product innovation. Bansal and Kumar, (2013) studied ecotourism for community development in Great Himalayan national park from stakeholders perspective.

Similarly Agarwal et al. (2013) studied stakeholder's role towards promotion of ecotourism in Himachal Pradesh. Worldwide multiple countries are increasingly becoming dependent on tourism, as it is one of the most rational and sustainable development choices that have the capability of creating employment to the communities and also acting as a main provision of foreign earnings to the economy (UNWTO, 2010 - Tourism and the Millennium Development Goals). Increasing competiveness amongst countries has also pushed the business capacity of the tourism industry to the level of, or, sometimes even exceeding trade commodities such as oil and food exports (UNWTO, 2011). While it is often the economic impacts of tourism that businesses and public organizations that are usually interested in (Stynes, 1999), the late twentieth century saw the emergence of environmental and socio-cultural impacts of tourism being controversial and critical issues discussed in tourism study. Peak periods of tourism can benefit the economy of a country, however on the expense of the locals, who might have to pay for the higher prices of goods and services in the community, thus increasing their cost of living. The contributions of tourism to a country's economic benefits is relative to factors such as the availability of facilities and resources, the country's social and political stability, the host communities' behavior towards tourist and the amount of investment injected by the government into tourism projects and development (Youell, 1998). 
According to Wall and Mathieson (2006), more often than not, social tensions between host communities and tourists happens in developing countries whereby the tourist market are from a country with higher foreign currency rate than the host communities and thus unintentionally highlighting the disparity of wealth. They also mentioned that since the nature of tourism involves the movement of people around geographical locations, social conflicts occur as a result of differences in cultures, values, lifestyles and languages. Despite of the positive and inspiring socio-cultural impacts of tourism on a host environment, the negative impacts of tourism, on the other hand, can equally cause a prominent damage on a culture. Ironically, instead of reviving a lost culture, the continuous development of tourism driven by the influx of tourist demand can very well cause the same cultural identity and value of the host communities to change and this issue has raised concerns amongst tourism organizations. This normally happens when local communities conformed to the needs, wants and desires of tourist's expectations in the bid to respond to their growing demands.

A recent study by Tsai et. al., (2016) suggests that global climate patterns have undergone dramatic changes since 1990s, often resulting in weatherinduced natural disasters that have caused widespread environmental damage. Such conditions raise serious threats to communities that are dependent on natural resources and ecosystem services for tourism development.

However on the positive note, Kreag (2011) states that the increased interest of tourists into the culture and traditions of the local society also helps to push the demand for historical and cultural education and local tourism agencies will be pressured to step up on preservation and conservation of possible endangered ancient sites, monuments or artifacts. A key intention behind government support for tourism in any country either fully diversified developed economy or a less developed country, is tourism's ability to create employment opportunities and hence contribute to the overall economic and social development of a nation. Nowadays visitors are turning out to be more modern and their need to recover the past has been expanding. They have been visiting heritage destinations more repeatedly. Consequently this review is in consistence with fascination traits and trends those draw the visitors to a tourist site and effects of tourism on these sites.

\section{Research gap}

The following research gap has been identified on the basis of literature review:

There has been a growing body of literature that addresses tourism as a viable economic option for local community development. However, there is little evidence on the literature that depicts the nature of interaction between local communities and tourism development, which is one of core elements for developing a viable tourism industry in a destination. While the literature recognizes that the inclusion of the local community in tourism development is considerable, there have been some debates about their role.

- The destinations relay on the resident's accord towards any kind of tourism activity either developed or proposed. Local community may oppose any tourism developments due to multiple human stakes and beliefs. Therefore, before suggesting tourism development, it is mandatory to keep in mind the local factors, satisfaction of tourist and the community stake towards tourism development.

- Since the cultural background of the majority of heritage tourists differs vastly from that of their hosts, the influence of culture on the interpersonal contact between tourists and hosts requires analysis.

\section{Research Objectives}

1. To identify the factors, determining the success of heritage tourism in Himachal Pradesh.

2. To study the role of various stakeholders for the success of heritage tourism promotion.

3. To identify the major challenges and suggest practical measures for the development of heritage tourism in Himachal Pradesh. 


\section{DATABASE AND RESEARCH METHODOLOGY}

The survey was conducted on 120 respondents who were identified as stakeholders of heritage of Himachal Pradesh. In an attempt to validate the data collection techniques and check comprehensibility and whether the responses received would provide the information sought, a pilot survey was conducted nearby Kangra Fort in District Kangra of Himachal Pradesh, India in August 2013. The sampling procedure used to pre-test the questionnaires for stakeholders was purposive sampling. Questionnaire was pretested for evaluating reliability and validity. For ensuring the content validity of the scale items, items were examined by 2 academicians possessing more than 10 years of experience in the related field of study. Before submitting questionnaire for pilot testing all the suggestions of evaluators/experts were incorporated. For pilot testing questionnaire was administered on 50 stakeholders respectively from district Kangra. All the items on which respondents faced difficulty were revised in wording. Reliability of scale items were assessed through Cronbach alpha (a). Sampling plan in the research was interview and questionnaire. In addition various books, journals, newspapers, magazines and various reports related to the topic, primary information were also gathered through the visits to the libraries, museums and historic places the destinations selected for survey were visited at least twice a year. The questionnaire for stakeholders, based on the research objectives was filled by the total population size of 120 . These different questionnaires were administered on stakeholder groups (local residents, tourism related business owners, representatives of government). SPSS was used for analysis of primary data in the present study.

\section{ANALYSIS AND INTERPRETATION}

In order to identify the factors, measuring opinions of stakeholders towards impact of tourists on destination attributes in Himachal Pradesh, 25 statements/items were taken for further analysis (Table 2). Factor analysis was applied on these statements to identify underling structure among these statements. Factor analysis provides the
Table 2. Statements of factors, measuring opinions of stakeholders towards impact of tourists on destination attributes in Himachal Pradesh

\begin{tabular}{|c|c|}
\hline $\begin{array}{l}\text { Item } \\
\text { No }\end{array}$ & Statement \\
\hline 1. & $\begin{array}{l}\text { Hosts and guests interactions create a better } \\
\text { cultural understanding }\end{array}$ \\
\hline 2. & $\begin{array}{l}\text { Tourism can push up local property prices and the } \\
\text { cost of goods and services resulting into inflation }\end{array}$ \\
\hline 3. & $\begin{array}{l}\text { Local businesses are benefiting economically from } \\
\text { tourism }\end{array}$ \\
\hline 4. & $\begin{array}{l}\text { Our region has integrated cultural offerings } \\
\text { (festivals/events/music/storytelling) into our tourism } \\
\text { product }\end{array}$ \\
\hline 5. & $\begin{array}{l}\text { Our destination is trying to expand tourism } \\
\text { services in off seasons }\end{array}$ \\
\hline 6. & $\begin{array}{l}\text { The tourism industry in my region is } \\
\text { environmentally sustainable }\end{array}$ \\
\hline 7. & There is a clear marketing brand for our region \\
\hline 8. & $\begin{array}{l}\text { Tourism is well-developed in my region/ } \\
\text { community }\end{array}$ \\
\hline 9. & $\begin{array}{l}\text { Tourism helps to promote conservation of wildlife } \\
\text { and natural resources such as forests, rivers, rocks } \\
\text { etc. as these are now regarded as tourism assets }\end{array}$ \\
\hline 10. & Jobs created by tourism are often seasonal \\
\hline 11. & $\begin{array}{l}\text { The marketing efforts for our region are } \\
\text { well-coordinated }\end{array}$ \\
\hline 12. & Tourism has created jobs for local people \\
\hline 13. & $\begin{array}{l}\text { Construction of hotels \& tourist facilities has } \\
\text { destroyed the natural environment }\end{array}$ \\
\hline 14. & $\begin{array}{l}\text { Tourism provides opportunities for small-scale } \\
\text { business enterprises }\end{array}$ \\
\hline 15. & My/our businesses have an environmental policy \\
\hline 16. & $\begin{array}{l}\text { Tourism also causes increased pollution through } \\
\text { traffic emissions, littering, increased sewage } \\
\text { production and noise }\end{array}$ \\
\hline 17. & $\begin{array}{l}\text { Tourism has attracted investment to develop } \\
\text { infrastructure }\end{array}$ \\
\hline 18. & $\begin{array}{l}\text { Tourism encourages the preservation of local } \\
\text { culture \& Tradition }\end{array}$ \\
\hline 19. & $\begin{array}{l}\text { Natives of the destination act as agents for tourism } \\
\text { promotion }\end{array}$ \\
\hline 20. & $\begin{array}{l}\text { Our region is maximizing the use of technology in } \\
\text { promoting tourism }\end{array}$ \\
\hline 21. & $\begin{array}{l}\text { Enterprises in our region offer quality customer } \\
\text { service }\end{array}$ \\
\hline 22. & $\begin{array}{l}\text { The website for our region is beneficial to my } \\
\text { business }\end{array}$ \\
\hline 23. & Tourism is important to my region and community \\
\hline 24. & $\begin{array}{l}\text { Our region receives technical and financial } \\
\text { support from universities and government agencies } \\
\text { on tourism and industry trends }\end{array}$ \\
\hline 25. & $\begin{array}{l}\text { There is adequate availability of information } \\
\text { about various tourist destinations situated inside } \\
\text { Himachal Pradesh }\end{array}$ \\
\hline
\end{tabular}




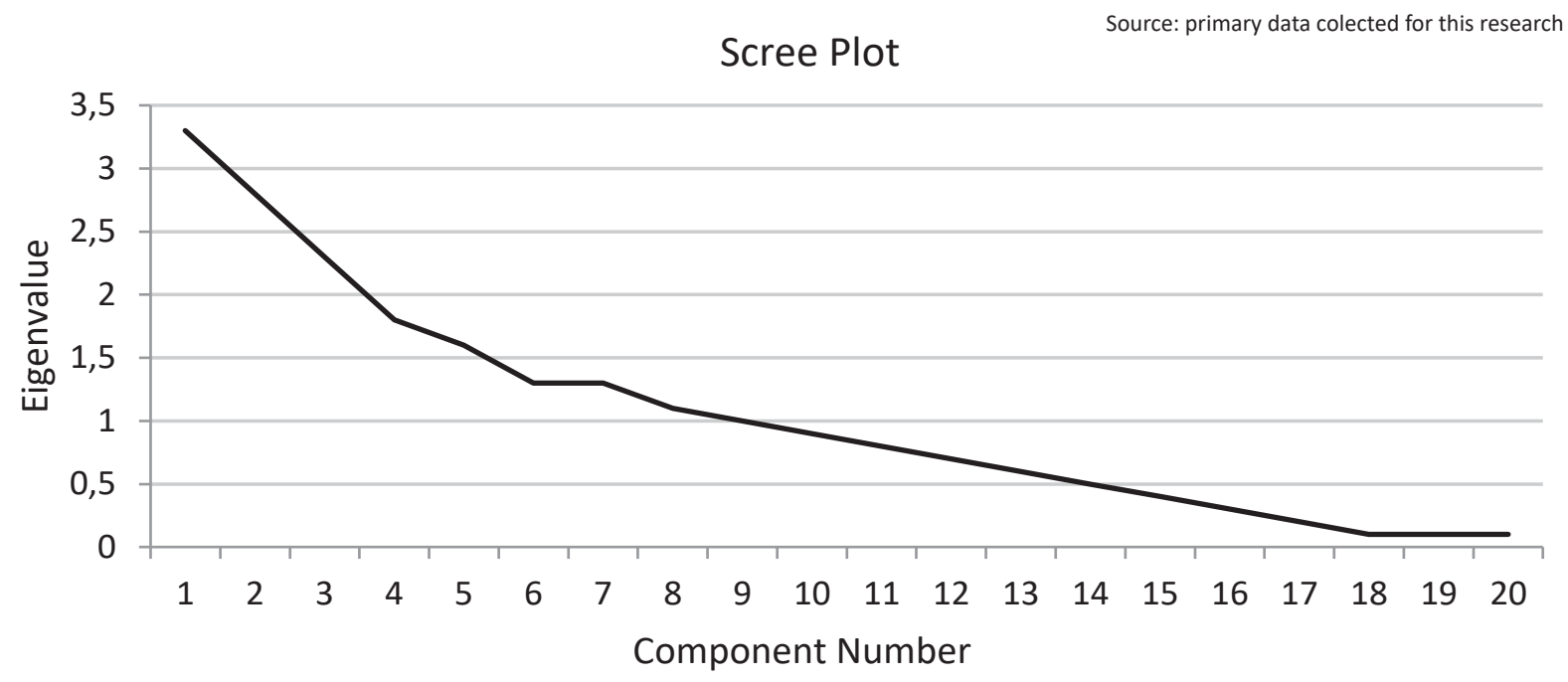

Figure 2. Scree plot for the statements related to heritage tourism site attributes in Himachal Pradesh

tools for analyzing the structure of the interrelationships (correlations) among a large number of variables (e.g., test scores, test items, questionnaire responses) by defining sets of variables that are highly interrelated, known as factors. These groups of variables (factors), which are by definition highly inter-correlated, are assumed to represent dimensions within the data (Hair et al., 2013). Item number 2, 10, 13 and 16 are negatively worded items hence they were reverse coded before applying factor analysis.

EFA was employed on statements measured on a seven-point scale (least satisfied-highly satisfied) to identify factors measuring opinions of stakeholders towards impact of tourists on destination attributes in Himachal Pradesh. Table 3 shows the values of Kaiser-Meyer-Olkin (KMO) measure of sampling adequacy and Bartlett's Test of sphericity.

Kaiser-Meyer-Olkin Measure of Sampling Adequacy is a measure to quantify the degree of inter-correlations among the variables and the appropriateness of factor analysis is the measure of sampling adequacy (MSA). This measure varies between 0 and 1 , and values closer to 1 are better. The value of $\mathrm{KMO}$ is 0.62 , which is mediocre (Hair et al.). Bartlett's Test of sphericity is significant which provides the statistical significance that the correlation matrix has significant correlations among at least some of the variables (Hair et al.).
Table 3. KMO and Bartlett's Test for the statements related to impact of tourists on destination attributes in Himachal Pradesh

Source: primary data colected for this research

\begin{tabular}{|c|c|c|}
\hline \multicolumn{2}{|c|}{$\begin{array}{l}\text { Kaiser-Meyer-Olkin Measure } \\
\text { of Sampling Adequacy }\end{array}$} & 0.620 \\
\hline \multirow{3}{*}{$\begin{array}{l}\text { Bartlett's Test } \\
\text { of Sphericity }\end{array}$} & $\begin{array}{l}\text { Approx. } \\
\text { Chi-Square }\end{array}$ & 2564.100 \\
\hline & $d f$ & 190 \\
\hline & Sig. & 0.000 \\
\hline
\end{tabular}

The scree plot shown in Figure 2 demonstrates distribution of variance among the components graphically. The variance of each component is less than the preceding one. The curve shows an "elbow" at a given value on the $x$-axis, this is often taken as indicating that higher order principal components contribute a decreasing amount of additional variance and so might not be needed (Landau \& Everitt, 2004). Scree plot shows a marked decrease in downward slope after the fourth principal component implying that we can summarize our twenty heritage tourism site attributes variables by the seven principal components.

Table 4 shows results of principal component analysis after varimax rotation, Eigen values, the percentage of variance and cumulative percentage of total variance extracted by successive factors. Principal Component Analysis was employed for extracting the factors based on Latent Root 
Table 4. Principal Component Analysis with Varimax Rotation for the statements related to impact of tourists on destination attributes in Himachal Pradesh

\begin{tabular}{|c|c|c|c|c|c|c|c|c|c|}
\hline \multirow{2}{*}{ No } & \multirow{2}{*}{ Statements } & \multicolumn{7}{|c|}{ Factors } & \multirow{2}{*}{ Communalities } \\
\hline & & 1 & 2 & 3 & 4 & 5 & 6 & 7 & \\
\hline 1. & $\begin{array}{l}\text { Tourism has created jobs for local } \\
\text { people }\end{array}$ & 0.988 & 0.024 & -0.026 & 0.041 & 0.052 & -0.103 & -0.023 & 0.993 \\
\hline 2. & $\begin{array}{l}\text { Local businesses are benefiting } \\
\text { economically from tourism }\end{array}$ & 0.985 & 0.026 & -0.027 & 0.042 & 0.052 & -0.096 & -0.031 & 0.986 \\
\hline 3. & $\begin{array}{l}\text { Tourism has attracted investment to } \\
\text { develop infrastructure }\end{array}$ & 0.979 & 0.023 & -0.046 & 0.048 & 0.034 & -0.125 & -0.013 & 0.980 \\
\hline 4. & $\begin{array}{l}\text { The website for our region is } \\
\text { beneficial to my business }\end{array}$ & 0.024 & 0.928 & 0.04 & 0.004 & 0.037 & -0.152 & -0.043 & 0.890 \\
\hline 5. & $\begin{array}{l}\text { There is a clear marketing brand for } \\
\text { our region }\end{array}$ & 0.017 & 0.897 & -0.008 & 0.039 & 0.028 & -0.098 & -0.081 & 0.823 \\
\hline 6. & $\begin{array}{l}\text { Natives of the destination acts as } \\
\text { agents for tourism promotion }\end{array}$ & -0.019 & 0.800 & 0.006 & 0.086 & 0.08 & 0.078 & -0.097 & 0.670 \\
\hline 7. & $\begin{array}{l}\text { The marketing efforts for our region } \\
\text { are well-coordinated }\end{array}$ & 0.095 & 0.524 & -0.068 & -0.309 & -0.193 & 0.329 & 0.172 & 0.559 \\
\hline 8. & $\begin{array}{l}\text { Our region has integrated cultural } \\
\text { offerings (festivals/events/music/ } \\
\text { storytelling) into our tourism product }\end{array}$ & -0.048 & 0.011 & 0.896 & 0.035 & 0.041 & -0.021 & 0.08 & 0.815 \\
\hline 9. & $\begin{array}{l}\text { Tourism encourages the preservation } \\
\text { of local culture \& Tradition }\end{array}$ & -0.098 & 0.064 & 0.884 & 0.036 & 0.032 & 0.073 & 0.071 & 0.808 \\
\hline 10. & $\begin{array}{l}\text { Hosts and guests Interactions create } \\
\text { a better cultural understanding }\end{array}$ & 0.051 & -0.077 & 0.759 & -0.151 & 0 & 0.035 & -0.089 & 0.617 \\
\hline 11. & $\begin{array}{l}\text { Tourism also causes increased } \\
\text { pollution through traffic emissions, } \\
\text { littering, increased sewage } \\
\text { production and noise }\end{array}$ & 0.087 & -0.058 & 0.001 & 0.931 & -0.011 & 0.028 & 0.045 & 0.881 \\
\hline 12. & $\begin{array}{l}\text { Tourism helps to promote } \\
\text { conservation of wildlife and natural } \\
\text { resources such as forests, rivers, } \\
\text { rocks etc. as these are now regarded } \\
\text { as tourism assets }\end{array}$ & 0.042 & 0.077 & -0.089 & 0.904 & -0.054 & 0.058 & 0.03 & 0.840 \\
\hline 13. & $\begin{array}{l}\text { Tourism can push up local property } \\
\text { prices and the cost of goods and } \\
\text { services resulting into inflation }\end{array}$ & -0.018 & 0.085 & -0.035 & -0.073 & 0.831 & 0.023 & 0.07 & 0.710 \\
\hline 14. & $\begin{array}{l}\text { Tourism is important to my region } \\
\text { and community }\end{array}$ & 0.22 & -0.144 & 0.042 & 0.015 & 0.726 & -0.128 & -0.135 & 0.633 \\
\hline 15. & $\begin{array}{l}\text { Construction of hotels \& tourist } \\
\text { facilities has destroyed the natural } \\
\text { environment }\end{array}$ & -0.08 & 0.231 & 0.142 & 0.335 & 0.465 & 0.256 & 0.287 & 0.556 \\
\hline 16. & $\begin{array}{l}\text { Our destination is trying to expand } \\
\text { tourism services in off seasons }\end{array}$ & -0.195 & -0.247 & -0.162 & 0.122 & -0.101 & 0.655 & -0.03 & 0.580 \\
\hline 17. & $\begin{array}{l}\text { Tourism provides opportunities for } \\
\text { small-scale business enterprises }\end{array}$ & 0.165 & 0.221 & -0.01 & 0.158 & -0.197 & 0.633 & 0.173 & 0.571 \\
\hline 18. & $\begin{array}{l}\text { Tourism is well-developed in my } \\
\text { region/community }\end{array}$ & 0.025 & 0.367 & 0.299 & 0.017 & -0.217 & 0.5 & 0.12 & 0.536 \\
\hline 19. & $\begin{array}{l}\text { The tourism industry in my region is } \\
\text { environmentally sustainable }\end{array}$ & 0.061 & 0.044 & 0.084 & 0.05 & -0.103 & -0.132 & 0.76 & 0.621 \\
\hline \multirow[t]{4}{*}{20.} & $\begin{array}{l}\text { Our region is maximizing the use of } \\
\text { technology in promoting tourism }\end{array}$ & 0.019 & -0.103 & 0.157 & 0.126 & -0.086 & -0.246 & 0.672 & 0.571 \\
\hline & Eigen Values & 3.034 & 2.738 & 2.304 & 1.861 & 1.561 & 1.342 & 1.226 & \multirow{3}{*}{-} \\
\hline & Percentage of Variance & 15.171 & 13.691 & 11.519 & 9.307 & 7.803 & 6.712 & 6.130 & \\
\hline & Cumulative Percentage of Variance & 15.171 & 28.862 & 40.381 & 49.687 & 57.490 & 64.202 & 70.333 & \\
\hline
\end{tabular}


Criterion (i.e. Eigen value $>1$ ) for the number of factors to be extracted. An Eigen value of 1.00 is the most commonly used criterion for deciding how many factors to retain in factor reduction (Bryant \& Yarnold, 1998; Cattell, 1966; Stevens, 1996). Derived factors explain $70.33 \%$ of total variance which is above the minimum limit of $60 \%$ in social sciences (Hair et al.). The percentages of variance extracted by factor 1 to 7 are 15.17, 13.69, $11.52,9.31,7.80,6.71$ and 6.13 respectively. Last column of table shows values of communalities corresponding to each item. Communalities explain the amount of variance in a variable that is accounted for by the four factors taken together.

All of the communalities (except item 15) were ensured to exceed value of 0.50 before performing the rotation of the factor matrix (Hair et al.). Item 15 was retained due to its enormous contribution in the present study. Rotated factor 1 seems almost exclusively associated with item. 3, 12 and 17 which were named as heritage tourism attribute of economic effects. Rotated factor 2 appears most closely associated with variables 7,11 , 19 and 22 which were chosen as heritage tourism attributes of promotional measures. Rotated factor 3 appears most closely linked with variables 1,4 and 18 which were chosen as heritage tourism attributes of socio-cultural influences. Rotated factor 4 appears most closely linked with variables 9 and 16 which were chosen as heritage tourism attributes of impact on natural resources. Rotated factor 5 appears most closely linked with variables 2,13 and 23 which were chosen as heritage tourism attributes of impact on goods prices and environment. Rotated factor 6 appears most closely linked with variables 5, 8 and 14 which were chosen as heritage tourism attributes of development and opportunities. Rotated factor 7 appears most closely linked with variables 6 and 20 which were chosen as heritage tourism attributes of technology and sustainability. All the items load highly with their respective factors, loading is considered to be "large" if its absolute value exceeds 0.40 (Rourke et. al, 2013).

In order to check whether opinions of stakeholders differ significantly across districts on impact of tourists on destination attributes in Himachal Pradesh, following hypothesis was tested:

Table 5. Post-Hoc contrasts for district wise opinions of stakeholders on economic effects of tourism on tourism destination attributes

\begin{tabular}{|c|c|c|c|c|c|c|c|}
\hline \multirow{2}{*}{ Post Hoc Tests } & \multirow{2}{*}{\multicolumn{2}{|c|}{ District }} & \multirow{2}{*}{$\begin{array}{c}\text { Mean } \\
\text { Difference }\end{array}$} & \multirow{2}{*}{ Std. Error } & \multirow{2}{*}{ Sig. } & \multicolumn{2}{|c|}{$\begin{array}{c}95 \% \\
\text { Confidence Interval }\end{array}$} \\
\hline & & & & & & $\begin{array}{l}\text { Lower } \\
\text { Bound }\end{array}$ & $\begin{array}{l}\text { Upper } \\
\text { Bound }\end{array}$ \\
\hline \multirow{9}{*}{ Tukey HSD } & \multirow{3}{*}{ Shimla } & Kullu & 0.262 & 0.204 & 0.574 & -0.267 & 0.790 \\
\hline & & Kangra & 0.539 & 0.194 & 0.031 & 0.036 & 1.043 \\
\hline & & Chamba & -0.228 & 0.218 & 0.723 & -0.793 & 0.337 \\
\hline & \multirow{2}{*}{ Kullu } & Kangra & 0.278 & 0.194 & 0.483 & -0.226 & 0.781 \\
\hline & & Chamba & -0.489 & 0.218 & 0.115 & -1.054 & 0.075 \\
\hline & Kangra & Chamba & -0.767 & 0.209 & 0.002 & -1.309 & -0.225 \\
\hline & \multirow{3}{*}{ Chamba } & Shimla & 0.228 & 0.218 & 0.723 & -0.337 & 0.793 \\
\hline & & Kullu & 0.489 & 0.218 & 0.115 & -0.075 & 1.054 \\
\hline & & Kangra & 0.767 & 0.209 & 0.002 & 0.225 & 1.309 \\
\hline \multirow{9}{*}{ Games-Howell } & \multirow{3}{*}{ Shimla } & Kullu & 0.262 & 0.204 & 0.578 & -0.274 & 0.797 \\
\hline & & Kangra & 0.539 & 0.199 & 0.039 & 0.020 & 1.059 \\
\hline & & Chamba & -0.228 & 0.218 & 0.725 & -0.801 & 0.346 \\
\hline & \multirow{2}{*}{ Kullu } & Kangra & 0.278 & 0.192 & 0.474 & -0.224 & 0.780 \\
\hline & & Chamba & -0.489 & 0.212 & 0.106 & -1.047 & 0.068 \\
\hline & Kangra & Chamba & -0.767 & 0.207 & 0.002 & -1.310 & -0.224 \\
\hline & \multirow{3}{*}{ Chamba } & Shimla & 0.228 & 0.218 & 0.725 & -0.346 & 0.801 \\
\hline & & Kullu & 0.489 & 0.212 & 0.106 & -0.068 & 1.047 \\
\hline & & Kangra & 0.767 & 0.207 & 0.002 & 0.224 & 1.310 \\
\hline
\end{tabular}


Table 6. ANOVA results for role of government in tourism development in Himachal Pradesh

\begin{tabular}{|c|c|c|c|c|c|c|c|}
\hline No & Statements & & $\begin{array}{l}\text { Sum of } \\
\text { Squares }\end{array}$ & df & $\begin{array}{l}\text { Mean } \\
\text { Square }\end{array}$ & $\mathbf{F}$ & Sig. \\
\hline \multirow{3}{*}{1.} & \multirow{3}{*}{$\begin{array}{l}\text { Government is providing full support } \\
\text { to establish Tourism Product }\end{array}$} & Between Groups & 1.669 & 3 & 0.556 & 0.222 & 0.881 \\
\hline & & Within Groups & 441.859 & 176 & 2.511 & - & - \\
\hline & & Total & 443.528 & 179 & - & - & - \\
\hline \multirow{3}{*}{2.} & \multirow{3}{*}{$\begin{array}{l}\text { E-Travel Trade Recognition scheme } \\
\text { launched by Government is beneficial } \\
\text { for tourism related enterprises }\end{array}$} & Between Groups & 11.888 & 3 & 3.963 & 1.682 & 0.173 \\
\hline & & Within Groups & 414.556 & 176 & 2.355 & - & - \\
\hline & & Total & 426.444 & 179 & - & - & - \\
\hline
\end{tabular}

$\mathbf{H}_{0}$ 1: Factors measuring opinions of stakeholders towards impact of tourists on destination attributes in Himachal Pradesh do not differ across districts.

To test the hypotheses, independent one way ANOVA was performed. A significant difference was found across districts for economic impacts.

Table 5 shows the district wise difference of opinions of stakeholders on economic effects of tourism on heritage tourism destination attributes calculated from tukey HSD and Games-Howell method for economic effects of tourists on destination attributes in Himachal Pradesh. Results of both tests depicts that stakeholders opinion from Shimla districts is significantly different from Kangra district and stakeholders opinion from Kangra districts is significantly different from Chamba district, $\mathrm{P}<0.05$. So, the economic effects of tourism from Shimla district was significantly higher than from Kangra district and economic effects of tourism from Chamba district was significantly higher than from Kangra district.

In order to check whether opinion of stakeholders differ significantly across districts regarding role of government in tourism development in Himachal Pradesh, following hypothesis was tested:

\section{$\mathbf{H}_{0}$ 2: Opinion of stakeholders regarding role of gov- ernment in tourism development in Himachal Pradesh do not differ across districts.}

To test the hypotheses $\mathrm{H}_{0} 2$, independent one way analysis of variance (ANOVA) was performed. Before performing the independent ANOVA, it was assured that assumptions of normality of sampling distribution are fairly met and the data are measured on an interval scale. Skewness and kurtosis values for all factors across all districts are within the acceptable limits of normal distribution $(+/-2)$. So, the distribution can be accepted as fairly normal. Table 6 depicts the ANOVA statistics for difference in the opinions of stakeholders across districts for role of government in tourism development in Himachal Pradesh. There is no significant difference in the opinions of stakeholders from various districts for role of government in providing support to establish Tourism Product, $F$ value $(3,176)=0.22, p>0.05$, and for E-Travel Trade Recognition scheme launched by Government is beneficial for tourism related enterprises $\mathrm{F}$ value $(3,176)=1.68, \mathrm{p}>0.05$.

Table 7 shows the district wise difference of opinions of stakeholders for the role of government in developing activity based tourism and for developing religious/pilgrimage tourism, calculated from tukey HSD and Games-Howell method. Results of both tests depict that shows no difference between districts on stakeholders opinion for role of government in developing activity based. However, significant difference across districts was shown by both the tests for role of government in developing religious/pilgrimage tourism. Shimla districts is significantly different from Kangra district and stakeholder's opinion from Kullu districts is significantly different from Kangra district, $\mathrm{P}<0.05$. So, satisfaction of stakeholders from role of government in developing religious/pilgrimage tourism from Shimla district was significantly lower than from Kangra district. Satisfaction of stakeholders from role of government in developing religious/ pilgrimage tourism from Kullu district was significantly lower than from Kangra district. 
Table 7. Post Hoc contrasts for role of government in tourism development in Himachal Pradesh

Source: primary data colected for this research.

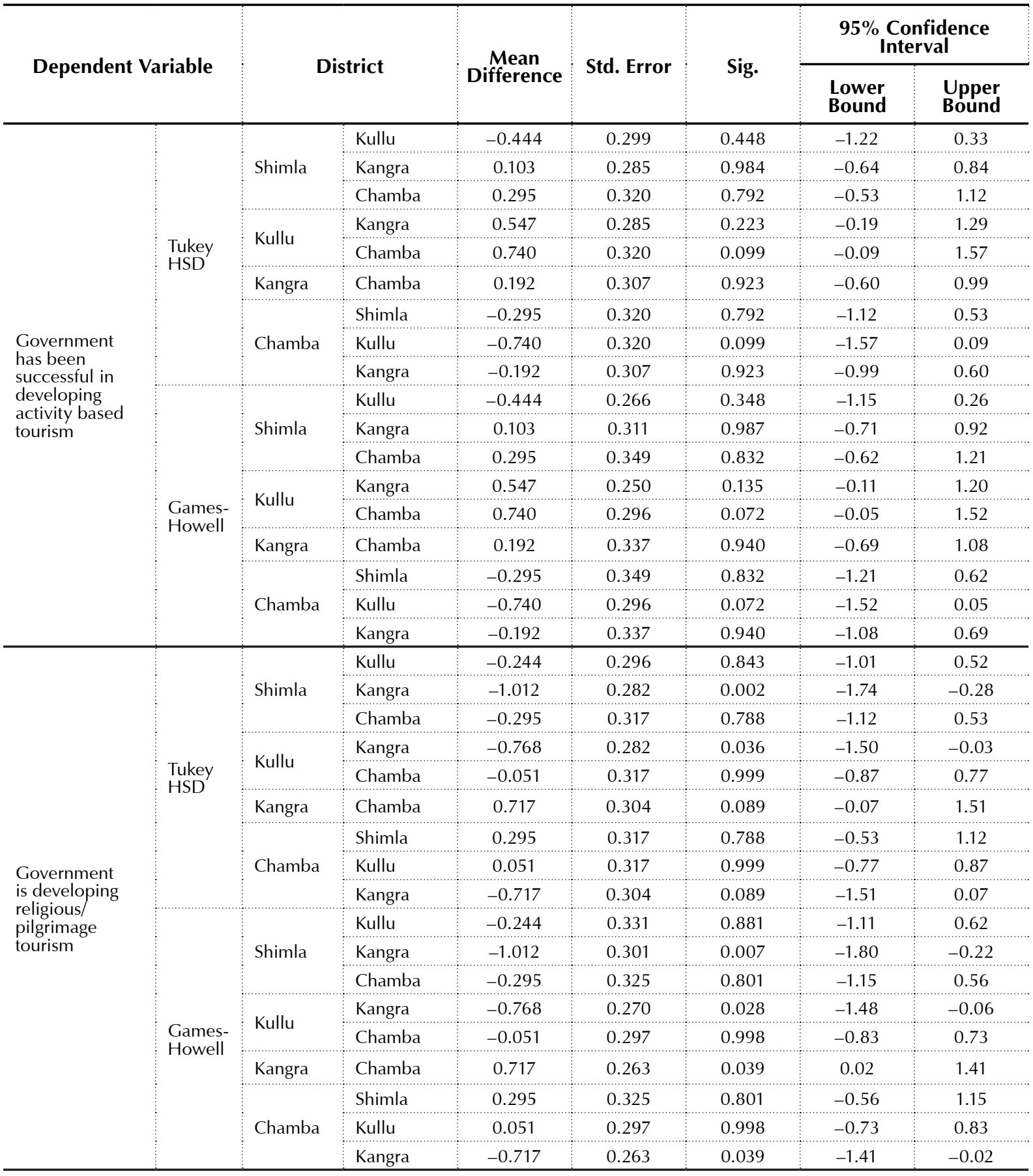

\section{FINDINGS OF STUDY}

Results of EFA revealed seven factors related to opinions of stakeholders towards impact of tourists on destination attributes in Himachal Pradesh. These seven factors were named as Economic Effects (F1), Promotional Measures
(F2), Socio-Cultural Influences (F3), Impact on Natural Resources (F4), Impact on Goods Prices \& Environment (F5), Development \& Opportunities (F6), Technology \& Sustainability (F7). The opinion of stakeholders towards impact of tourists on destination attributes from these factors was tested across districts. Out of all the above iden- 
tified factors, economic effects of tourism, shows significant difference in the opinions of stakeholders from various districts, F value $(3,176)=5.239$, $\mathrm{p}<0.05$. The indicators of economic effect are job created by tourism for local people. Local business benefits from tourism and attracted investment to develop infrastructure.

1. No significant difference in the opinions of stakeholders was found from various districts for role of government in providing support to establish Tourism Product, F value $(3,176)=$ $0.22, p>0.05$ but the district wise comparison of resources reflects the unequal development of the tourism product across the districts.

2. E-Travel Trade Recognition scheme launched by Government was found beneficial for tour- ism related enterprises $\mathrm{F}$ value $(3,176)=1.68$, $\mathrm{p}>0.05$.

3. The stakeholders marked that TVOA-ETA (Tourist visa on arrival-enabled with electronic Travel Authorization) scheme will bring more business to tourism enterprises $F$ value $(3,90.36)=0.74, \mathrm{p}>0.05$

4. Finally significant difference across districts was found for role of government in developing religious/pilgrimage tourism. Results indicate that, opinion of stakeholders towards Shimla districts is significantly different from Kangra district and stakeholder's opinion from Kullu districts is significantly different from Kangra district, $\mathrm{p}<0.05$.

\section{CONCLUSION}

Present research concludes that resident's acceptance of tourism is the key to the destination survival, therefore, it is suggested that government should ensure local community satisfaction while planning for tourism development. Close mentoring and monitoring mechanism for the tourism activities and initiatives by government may contribute towards holistic tourism development. The tourism sector is a major economic engine and generates a large part of the employment and business opportunities to the residents worldwide. To link the commitment from within the society to cultural heritage and use it for tourism attractions, could be an opportunity to boost the tourism sector and therewith employment levels. Furthermore, it would increase the attractiveness and competitiveness of the entire Himachal Pradesh Tourism. Preserving the world's cultural heritage for the enrichment and education of present and future generations is crucial. A great deal of tourism relies on places with natural, indigenous and historic significance which tourism products are based. In order to respect the cultural significance of the destination, people involve in tourism industry need to be sensitive to cultural groups who have a special interest in them and they need to directly involve in the planning and promotion of the destination. More importantly, different sectors have to recognize that heritage resources are the key for their own sustainability and they are not exogenous factors.

\section{Limitations of the study}

The present study has few limitations as under:

1. The tourism in Himachal Pradesh is seasonal in nature. The data collected during peak seasons can differ due to the uneven flow of tourists which may have the significant impact on the findings.

2. Any significant change due to new policies of government and natural environment, challenges identified under present study will limit the applicability of its results in future.

3. In present study selection of sample has been made following quota and judgment sampling. Therefore study is prone to the limitations of non probability sampling. 


\section{Scope for further research}

The replication of the study at other districts of the state and different regions of India and overseas with similar destination attributes would confirm the generalizability of the findings inferred by the present study. Identified factors in the present study have been evaluated on the basis of demographical and geographical characteristics. Relationships between these factors may be further extended to check the presence of structure between them.

\section{REFERENCES:}

1. Agarwal, S., Bhatt, A., Kapoor, N., Moutinho, T., Van Herwarde, G., \& Walker, K. (2013). Promoting Ecotourism in Himachal Pradesh.

2. Ashworth, G. J. (2000). Heritage, tourism and places: a review. Tourism Recreation Research, 25(1), 19-29.

3. Baker, M. J., \& Cameron, E. (2008). Critical success factors in destination marketing. Tourism and hospitality research, 8(2), 79-97.

4. Bansal, S. P., \& Kumar, J. (2013) Ecotourism for Community Development: A Stakeholder's Perspective in Creating a Sustainable Social Ecology Using Technology-driven Solutions. International Journal of Social Ecology and Sustainable Development, 2(2), 31-40.

5. Batta, R. N. (2003). Tourism's Potential for Financing Conservation Areas: A Study of KufriChail-Naldehra Area of Himachal Pradesh, India. Tourism Recreation Research, 28(1), 57-65.

6. Bryant, Fred B., \& Paul, R. Yarnold. (1995). Principal-components analysis and exploratory and confirmatory factor analysis. APA.

7. Campanella, M. (2013). Establishing tourist places: between social constructivism and phenomenology. Doctoral dissertation, Tartu Ülikool.

8. Cattell, R. B. (1966). The scree test for the number of factors. Multivariate Behavioural Research, 1, 245-276.

9. Donaldson, T., \& Preston, L. E. (1995) The Stakeholder Theory of the Corporation: Concepts, Evidence, and Implications. Academy of Management Review, 20, 65-91.
10. Freeman, R. E. (1984). Strategic management: A stakeholder approach. Boston: Pitman.

11. Fyall, A., \& Garrod, B. (1998). Heritage tourism: at what price? Managing Leisure, 3(4), 213-228.

12. Hair, J. F., Black, W. C., Babin, B. J., Anderson, R. E., \&Tatham, R. L. (2013). Multivariate data analysis (Vol. 6). Upper Saddle River, NJ: Pearson Prentice Hall.

13. Himachal Pradesh Economic Survey 2014-2015. Retrieved from http://admis.hp.nic.in/himachal/ economics/pdfs/EconomicSurveyEng2014_15_A1b.pdf

14. Hollinshead, K. (1999). Surveillance of the worlds of tourism: Foucault and the eye-of-power. Tourism Management, 20(1), 7-23.

15. Yale, P. (1991). From tourist attractions to heritage tourism. Huntingdon: ELM Publications.

16. Jamal, T., \& Kim, H. (2005). Bridging the interdisciplinary divide Towards an integrated framework for heritage tourism research. Tourist Studies, 5(1), 55-83.

17. Kreag, G. (2001). The impacts of tourism: Minnesota Sea Grant Program.

18. Mathieson, A. (2006). Tourism, economic, physical and social impacts. Longman.

19. McCain, G., \& Ray, N. M. (2003). Legacy tourism: The search for personal meaning in heritage travel. Tourism Management, 24(6), 713-717.

20. Morgan, N., \& Pritchard, A. (2003). Tourism, promotion and power. London: Wiley.
21. Mowforth, M., \& Munt, I. (2015). Tourism and sustainability: Development, globalisation and new tourism in the third world. Routledge.

22. Poria, Y., Butler, R., \& Airey, D. (2003).The core of heritage tourism. Annals of Tourism Research, 30(1), 238-254.

23. Prentice, R. (2001). Experiential cultural tourism: Museums \& the marketing of the new romanticism of evoked authenticity. Museum Management and Curatorship, 19(1), 5-26.

24. Richards, G. (2000). Tourism and the world of culture and heritage. Tourism recreation research, 25(1), 9-17.

25. Schumacher, H. J. (2007). Let's Talk Europe: Ecotourism. Business World, p. S, 1.

26. Shah, K., \& Gupta, V. (2000). Tourism, the poor and other stakeholders: Experience in Asia. C. Boyd (Ed.). London: Overseas Development Institute.

27. Silberberg, T. (1995).Cultural tourism and business opportunities for museums and heritage sites. Tourism Management, 16(5), 361-365.

28. Singh, S. (2008). Destination development dilemma - Case of Manali in Himachal Himalaya. Tourism Management, 29(6), 11521156.

29. Stevens, B. F. (1996). Price value perceptions of travelers. Journal of Travel Research, 31(2), 44-48.

30. Timothy, D. J., \& Boyd, S. W. (2003). Heritage tourism. Harlow, England: Pearson. 
31. Timur, S., \& Getz, D. (2008). A network perspective on managing stakeholders for sustainable urban tourism. International Journal of Contemporary Hospitality Management, 20(4), 445-461.

32. Tsai, C. H., Wu, T. C., Wall, G., \& Linliu, S. C. (2016). Perceptions of tourism impacts and community resilience to natural disasters. Tourism Geographies, 18(2), 152-173.

33. Tunbridge, J. E., \& Ashworth, G. J. (1996). Dissonant heritage: the management of the past as a resource in conflict. John Wiley \& Sons.

34. UNESCO, W. CONFERENCES AND SEMINARS. (2015).
UNWTO/UNESCO World Conference on Tourism \& Culture. Retrieved March 2016 from http://www.e-unwto.org/doi/ pdf/10.18111/9789284417360

35. UNESCO. (2005). World Heritage. Retrieved from http://whc.unesco. org/ (accessed on Jan 2013).

36. UNESCO/World Commission on Culture and Development. (1995). Our creative diversity. Report of the World Commission on Culture and Development. Retrieved Aug 2015 from http://unesdoc.unesco. org/images/0010/001055/105586e. pdf (accessed on August 2015).

37. Vasudevan, Smitha. (2008). The role of internal stakeholders in destination branding:

Observations from Kerala

Tourism. Place Branding and

Public Diplomacy, 4(4), 331-335.

38. Walton, J., \& Cooper, C.

(2011). Tourism and history. Good fellow Publishers. Retrieved from http://books.google.com (accessed Feb 2014).

39. Yale. P. (1991). From Tourist Attractions to Heritage Tourism ELM Publications, Huntingdon.

40. Youell, R. (1998). Tourism: an introduction. Addison Wesley Longman Ltd.

41. Zeppel, H., \& Hall, C. M. (1992). Arts and heritage tourism. Arts and heritage tourism, 47-68. 